\title{
Una elite dentro de la elite: El Casino Español de México entre el porfiriato y la revolución (1875-1915)
}

\author{
Ana Lía Herrera-Lasso
}

EL COLEGIO DE MÉXICO

\begin{abstract}
El presente artículo hace referencia al grupo de españoles que conformaron el Casino Español de México. La tesis central gira en torno a la idea de que este núcleo pasó, de un pequeño círculo de hombres españoles, a ser un importante y numeroso grupo cuyas relaciones con la elite política, económica y social de México fueron muy estrechas. Así, se puede hablar de una elite de españoles relacionados con la elite mexicana y diferenciados del resto de los españoles que vivían en México.
\end{abstract}

\section{INTRODUCCIÓN}

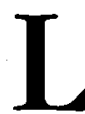

os orígenes del Casino Español de México son algo inciertos. Existen varias versiones al respecto, aunque ninguna parece del todo fundamentada. El año más comúnmente mencionado para su apertura es el de 1863, aunque hay quien marca el año anterior, como Michael Kenny. ${ }^{1}$ Otras versiones consultadas son, la primera, de Verónica Ordóñez quien dice que: "El Casino se fundó en 1863, cuando Manuel Mendoza Cortina y

${ }^{1}$ Kenny, Inmigrantes, 1979, p. 81.
José Toriello Guerra plantearon su idea a un grupo de compatriotas reunidos en una fiesta"; ${ }^{2}$ una segunda del propio Casino dice:

El Casino Español de México se constituyó el año de 1863, con el fin de que los españoles residentes en México tuvieran un lugar de esparcimiento y recreo espiritual, a la vez que un medio de estrechar su vida de relación con la sociedad mexicana. ${ }^{3}$

Las actas del propio Casino no dicen mucho al respecto ya que sólo

2 Ordoñez, "Colonia", 1990, p. 45.

${ }^{3}$ Folleto, pp. 3-4. 
existen a partir de 1875 . Finalmente, una última fuente consultada al respecto coincidiría con la de Kenny en cuanto al año de 1862, y se trata de un mensaje pronunciado por José Toriello Guerra, presidente del Casino en 1875. Toriello dice que la idea nació a partir de la Escuela Española de Música, creada también en 1862 , en cúya fundación "cerca de 300 individuos" se juntaron para conformar el Casino Español. El autor habla de que para fines de ese año ya estaban los estatutos y reglamentos y de ese modo la sociedad se pudo inaugurar definitivamente. ${ }^{4}$ Así, al parecer, el año de 1862 se puede considerar el de fundación. Sin embargo, como el propósito de este trabajo no es contar una historia del Casino Español, el dato no es imprescindible. Lo que sí trataré de hacer es estudiar el Casino como el punto de reunión de españoles en México, centrándome en un grupo muy selecto de sus miembros: hombres que se convirtieron en là elite de la colonia, tanto por su desarrollo económico como social.

Para adentrarme en este estudio me planteo las siguientes hipótesis. En primer lugar, que el Casino Español se convirtió en un lugar muy selectivo. En un principio fue el centro de reunión de unos cuantos españoles que, a partir de 1876, aprovechaban de la mejor manera la paz y la estabilidad del porfiriato, y que por lo mismo pudieron desarrollar en México sus negocios. Poco a poco la asociación fue creciendo, aunque no sin problemas, para llegar a la última década del siglo

\footnotetext{
${ }^{4}$ Toriello Guerra, "Primeros", 1998, p. 4.
}

XIX como un grupo bien consolidado, que alcanzó su máximo apogeo en los primeros diez años del siglo XX. Con la salida de Porfirio Díaz del poder en 1911, el Casino fue perdiendo influencia e importancia, aunque como asociación siguió siendo uno de los máximos representantes de los españoles en México.

En segundo lugar, sugiero que este grupo era en efecto reducido y selectivo, sobre todo respecto de los propios españoles. En un principio consistia en unos cuantos hombres desvinculados del resto de la sociedad mexicana y preocupados por no perder su relación con España. Conforme pasó el tiempo y sus miembros fueron creciendo en número y en importancia comercial e industrial, la relación con la elite mexicana fue cada vez mayor, hasta llegar a un punto, a finales del porfiriato, en que vieron abierto el campo para una cierta integración con la clase política, sobre todo entre los miembros de la Junta Directiva. Así, se formó un grupo que buscó no perder su identidad española, pero que quiso relacionarse con aquellos mexicanos que consideró sus iguales. Al resto de los españoles residentes en México, no favorecidos económicamente, los vio como un grupo inferior, $y$ frente al cual ellos representaron una especie de liderazgo.

Finalmente, el hecho de relacionarse con la elite económica y política del país les permitió entrar a un círculo de influencias que los llevó a tomar partido y apoyar ciertas políticas gubernamentales. Esto es muy claro a medida que se acerca el centenario de la independencia en 1910, en cuyos festejos 
cooperaron abierta y entusiastamente; y también al estallar la Revolución y rechazar al maderismo.

En resumen, trataré de analizar al Casino Español como un grupo español social y económicamente elitista que trató de buscar su identidad en México sin despegarse de España, pero que sufrió una transformación entre 1880 y 1910; y que a pesar de tener intensos e importantes intereses económicos en México, así como relaciones comerciales con los mexicanos, en un principio prefirió mantenerse alejado de las actividades sociales del país, y posteriormente, conforme pasaron los años y el siglo terminaba, se convirtió en una asociación que buscó influencias políticas y un lugar privilegiado dentro de las altas esferas sociales y políticas, y que llegó a su apogeo en el México de 1910.

La mayor parte de los españoles que llegaron México hacia las décadas finales del siglo XIX, lo hicieron cobijados por las políticas porfiristas a favor de la inmigración y por las malas condiciones económicas que se vivían en España, sobre todo en el campo. La mayoría de ellos eran hombres que venían dispuestos a trabajar de sol a sol para formar un patrimonio, ya fuera para regresar a España o para comenzar una familia en México. Los que se quedaban lo hacían con la idea de trabajar duramente hasta formar un "capital respetable para invertirlo en el negocio o para destinarlo a otras áreas económicas." Así se formaron numerosas compañías, industrias y negocios, sobre todo en la ciudad de México,

s Pérez, “Algunas", 1981, p. 135. lugar al que llegó el mayor número de españoles. Lo importante de este capital, asienta Josefina MacGregor, es que se volvía a invertir en México ya que fueron muy pocos los españoles que regresaron a su país. ${ }^{6}$ Los negocios crecieron, las industrias textileras comenzaron a ser dominadas por españoles, sobre todo en el área de Veracruz y Puebla; el comercio de abarrotes de la ciudad de México estaba prácticamente en sus manos. De esta forma, corno dice Clara Lida, "los inmigrantes españoles en México durante el porfiriato -y aún después- aparecían como una burguesía asentada en las ciudades más activas del país".

Poco a poco la colonia española fue creciendo hasta convertirse en la más numerosa entre las extranjeras en México. Por lo mismo, se pudo diferenciar de otras como la alemana, la inglesa, la francesa o la estadunidense que, aunque significativas, nunea se conformaron como un grupo importante dentro de la sociedad mexicana. Pero los españoles no solamente se diferenciaron del resto de los extranjeros del país, sino que también lo hicieron entre ellos, es decir, se conformaron sectores o grupos que mientras se consolidaban se fueron distinguiendo en su interior.

Como grupos ya diferenciados intentaron adentrarse en la sociedad mexicana y lo hicieron en un sector similar al propio: es decir, el grupo que se consideraba a sí mismo la elite de la colonia española buscó espacios den-

\footnotetext{
- MacGregor, México, 1992, p. 50.

${ }^{7}$ Lida, Inmigración, 1994, p. 35, e Inmigración, 1997, passim.
} 
tro de la alta burguesía mexicana dejando a un lado al resto de los peninsulares con los que no se identificaba. ${ }^{8}$ Otro sector con el que trataban de equipararse, y lo hicieron, fue el de la elite de las demás colonias extranjeras importantes en México, aunque sus actividades y desarrollo económico y político respecto del país fueron completamente diferentes, al igual que la estructura interna de sus residentes.

Así, el proceso de asimilación y.de búsqueda de identidad de los españoles en México no fue uno solo. Como dice Michael Kenny, sí se tenían "expectativas mutuas basadas tanto en la tradición ancestral como en una orientación futura," "9 pero éstas se encaminaron por vías diferentes en el sentido de que, para la alta burguesía comercial española, el grupo al que había que asimilarse era muy diferente al de los trabajadores españoles. Las actividades, actitudes, espacios y modos de enfrentamiento con la sociedad receptora fueron distintos, por lo que los resultados también lo fueron. De esta forma, el sector económico al que se pertenecía como inmigrante era fundamental dentro del proceso de asimilación, ya que fue el que determinó el grado y el tipo de contacto de los extranjeros con los diferentes grupos dentro de la sociedad mexicana.

\footnotetext{
${ }^{8}$ No hay que perder de vista el hecho de que las posiciones económicas y sociales que alcanzaron algunos de los españoles en México lo hicieron en este país, es decir, no fue una inmigración que llegara diferenciada económicamente, sino que en general, todos los hicieron con escasos recursos y en México conformaron su poder económico.

${ }^{9}$ Kenny, Inmigrantes, 1979, p. 61.
}

LA CONFORMACIÓN DE LA ELITE EN EL CASINO ESPAÑOL

Desde sus inicios, el Casino Español de México se fue perfilando hacia la conformación de un grupo selecto y cerrado. Como se dijo al comienzo, no existen datos sobre el origen de la asociación, por lo mismo se desconoce hasta ahora el número inicial de socios. El primer dato sobre los socios existentes es de 1875 y la cifra de entonces es $181 .^{10}$ Este reducido número de españoles tenía poca relación con la sociedad mexicana; en realidad lo que más les interesaba era no perder el contacto con España, y el Casino era un vehículo para ello. Los directivos de la sociedad en 1875, conscientes de tener tan pocos socios, se refieren al Casino como un reflejo de España, como "un altar a la patria ausente", tratando de esta forma de atraer un mayor número de miembros. ${ }^{11}$

La función de la sociedad era básicamente recreativa: tertulias, cafés, juegos de barajas y billar, reuniones y cenas para los propios miembros y para sus familias, etc. Estas reuniones servían también para ventilar temas de política y economía españolas, así como los últimos y más importantes eventos sociales. Los años setenta del siglo XX fueron sumamente conflictivos para España y el país se vio envuelto en graves disturbios políticos llegando a sufrir una guerra civil entre $\mathbf{1 8 7 2}$ y 1876. En los salones del Casino, en

${ }^{10}$ Biblioteca Archivo del Casino Español de México (en adelante BACEM), Libros de Actas núm. 1,12 de diciembre de 1875 , f. 45.

${ }^{11}$ Ibid. 
medio de partidas de baraja se defendían partidos y representantes políti$\cos$; aunque en general se podría decir que todos abogaban por el mismo bando, había quienes apoyaban a los monárquicos, así como a los centralistas. En esta época tan difícil, pertenecer al Casino se consideraba un deber patriótico entre sus miembros, que lo veían casi como una obligación ya que esta sociedad era la verdadera representante de la colonia española en México. $^{12}$

Podría pensarse que la participación política en los sucesos de la madre patria quedaba reducida a la discusión y a una preocupación, mayor o menor, por los familiares, los amigos y los intereses que habían dejado en España; sin embargo, la labor no quedó ahí. Los españoles, tanto en México como en Europa, fueron muy afectos a organizar suscripciones y reunir dinero para alguna causa que consideraban justa, y los miembros del Casino lo hicieron constantemente. Por ejemplo, el 14 de julio de 1875 se organizó una para los "heridos y mutilados" de la guerra carlista en España. En total se juntaron 8000 pesos de los cuales 6000 se mandarían a los soldados defensores del gobierno central, es decir, a la monarquía restaurada dirigida por Cánovas, quien intentaba un gobierno estable después de años de inestabilidad encabezados por la Revolución de 1868 y varios intentos en el poder de parte de liberales y conservadores. La monarquía constitucional intentó, entonces, conciliar con la mayor parte de los grupos, sin embargo los carlis-

${ }^{12}$ Ibid. tas tenían todavía la firme intención de llevar al trono a su propio candidato a dirigir la monarquía y con él instaurar un gobierno conservador que estuviera, además, muy apegado a la jerarquía católica. Los carlistas, empero, fueron vencidos en 1876 y la monarquía constitucional logró establecer. una relativa paz durante varias décadas.

Volviendo a la suscripción, la Junta acordó que el dinero restante, es decir 2000 pesos, fuera mandado a los carlistas. ${ }^{13}$ Con este hecho se puede ver que a pesar de que lo que buscaban era mantener una relación estrecha con España la realidad comenzó a perder espacio, es decir, se producía una idealización del país que los llevó a no diferenciar un bando político del otro y ver solamente compatriotas españoles; además existía una necesidad de no comprometerse desde lejos ya que los inmigrantes pertenecían a uno $\mathrm{u}$ otro bando.

Las suscripciones no solamente eran para cuestiones políticas, de hecho el mayor número de ellas se organizó para el alivio de víctimas de sucesos lamentables como inundaciones, choques, incendios, huracanes, etc. ${ }^{14} \mathrm{El}$ primer caso que encontré en este sentido fue para ayudar a los inundados de Valencia en 1875. A lo largo de los años estudiados se encontró lo mismo: se hicieron suscripciones para náufragos, para damnificados por tormen-

${ }^{13}$ Ibid., 30 de abril de 1878 , f. 19v.-20; Carr, España, 1966, pp. 330-340.

14 Ibid., 30 de octubre de 1879, fs. 36 v. -37. En esta fecha se da cuenta de la suscripción organizada para las víctimas de una tormenta en España. 
tas, para pescadores que perdieron sus navíos, etc. Lo mismo se hizo para españoles en México; por ejemplo, se crearon el Panteón Español y un colegio para españoles, así como se dio ayuda para algún compatriota en problemas y, posteriormente, para las víctimas de los sucesos revolucionarios de 1910 a 1915. Los españoles a los que se les daba alguna ayuda eran generalmente conocidos o familiares de los socios.

Las suscripciones, sobre todo en estos primeros años, son otra muestra del poco apego que los españoles tenían a la sociedad mexicana. No hay datos de que hayan organizado una sola de estas colectas para damnificados o víctimas mexicanos; parecería que solamente les eran importantes las cosas que sucedían en España o los españoles residentes fuera de su patria. Encontré, además, una referencia del mismo año 1875, donde los miembros del Casino se niegan a hacer una suscripción para beneficio de la sociedad "Amigos de la Reforma", probablemente una asociación mexicana de corte liberal. La respuesta fue negativa por no "estar en las facultades de la Junta molestar a los socios para atender a asunto alguno que no esté en relación con los intereses de esta sociedad". 15 .

La unión y el deseo de acercamiento con España no sólo era evidente a través de las suscripciones. También la llegada de españoles prominentes, ya fueran militares, representantes del gobierno o artistas, era importante para el Casino. Según de quien se tra-

\footnotetext{
${ }^{15}$ Ibid., 11 de marzo de 1875 , f. 2 v.
}

tara se celebraba de manera distinta. Por ejemplo, para cantantes o artistas se organizaban fiestas en la propia sociedad; para miembros destacados, ya fueran del gobierno o de la alta sociedad española, se hacían bailes o se les recibía de manera oficial, como fue el caso del señor Becerra Armesto, nuevo representante de España en México para quien se envió una comitiva de recepción a la estación del ferrocarril. ${ }^{16}$ El interés por los sucesos políticos y sociales de la península los llevaba a festejar las fechas nacionales de España en México; por ejemplo, se organizaban misas y actos religiosos por el onomástico o cumpleaños del rey; en 1875 se organizó un baile "con motivo del enlace de nuestro augusto soberano Don Alfonso XII". ${ }^{17}$ Por otro lado, si los sucesos eran trágicos, como tormentas, inundaciones, o cuestiones políticas que enlutaran a España, también afectaban al Casino. En ocasiones suspendieron bailes y tertulias, como durante la guerra carlista en que no hubo "tertulias familiares" hasta no "solemnizar la paz, por todos tan deseada". ${ }^{18}$

Esta cercanía con España debía significarse con la unión de todos los espańoles en México. Para eso se había fundado el Casino. El tono de las juntas directivas acerca de la unión es constante: "Afortunadamente a esta distancia de la madre patria, aunque las opiniones sean varias, no nos divi-

${ }^{16}$ BACEM, Libros de Actas núm. 2, 1886, f. $31 \mathrm{v}$.

${ }^{17}$ BACEM, Libros de Actas núm. 1, 27 de octubre de 1875 , f. $36 \mathrm{v}$.

${ }^{18}$ lbid., 12 de diciembre de 1875, f. 4. 
den odios políticos." ${ }^{19}$ Ideas similares se exponían sobre las diferencias regionales. Esto contribuía en gran medida a la idealización que se tenía sobre España y al deseo de concentrarse en un grupo fuerte y unido, pero poco relacionado socialmente con la sociedad que lo recibía. Pero esto poco pudo durar; como se verá más adelante, el aislamiento se fue dejando a un lado para dar paso a una socialización cada vez más fuerte.

Según la tesis de este ensayo, habría que matizar qué tipo de unión entre españoles era la que buscaban los miembros del Casino. Se ha dicho que era un grupo selecto y en este sentido pretendían encauzar la unión entre sus miembros. Parte de los residentes en México veían al Casino como el lugar ideal para relacionarse con sus iguales, con los españoles con quienes compartían los mismos intereses. Así se buscó fundar casinos en otras partes de la república que, aunque totalmente independientes, siempre mantuvieron cierta relación con el de la capital. Al parecer, esta idea surgió en el año de 1880 cuando se

inició la idea de que en cada estado y lugar de la República donde se reúnan más de tres españoles se formaran juntas para que estuvieran en relación con este centro $[\ldots]$ la junta cree que debe instarse para llevar a efecto el pensamiento y formar de este Casino una corporación respetable y de utilidad a los intereses de todos nuestros compatriotas en la república. ${ }^{20}$

19 Ibid., 1878, f. 25v.

${ }^{20}$ BACEM, Libros de Actas núm, 2, 26 de diciembre de 1880 , f. 46.
La intención no era ignorar a aquellos miembros de la colonia que no eran considerados iguales, simplemente el trato era distinto. A partir de 1876 los miembros de la Junta Directiva intentaron establecer clases sabatinas para trabajadores y empleados españoles. Es significativo ver las materias que querían impartir: aritmética, historia, literatura, filosofía y gramática castellana. ${ }^{21}$ La idea era proporcionar algo de cultura a aquellos españoles que abandonaron su patria con poca educación y que no la pudieron continuar aquí, así como para los analfabetos. Se instó a los españoles dueños de las tiendas de abarrotes a que permitieran a sus trabajadores asistir; sin embargo, para los comerciantes era más importante la ganancia que el que sus empleados supieran historia. Por otro lado, las materias son significativas porque se muestran como producto de una elite social; realmente poca aplicación práctica iban a tener las nociones de filosofía y de literatura, así como de esgrima y de inglés, clases que trataron de establecerse más adelante. Realmente nunca tuvieron éxito con la escuela sabatina aunque continuaron los intentos por instalarla hasta los primeros años de este siglo.

21 BaCEM, Libros de Actas núm. 1, 14 de mayo de 1876 , fs. 6-6v. Las fuentes consultadas no permiten saber si es que estas clases eran sobre temas de historia y literatura mexicanas o españolas, siendo las del viejo continente lo más probable. 
EL CASINO ESPAÑOL DECIDE SOCIAIIZAR

El que los socios del Casino Español quisieran mantenerse alejados de la sociedad mexicana no podía durar mucho tiempo. Pronto dio inicio un proceso de socialización que llegó por dos vías, complementarias e involuntarias. Por un lado, los españoles directivos del Casino y en general todos los socios, eran grandes hombres de negocios, ya que al Casino pertenecían los dueños de las tiendas de abarrotes, de fábricas textileras, y de grandes haciendas agrícolas. Durante, los primeros años del porfiriato estos negocios crecieron y en ocasiones se convirtieron en los más importantes dentro del ramo en todo el país. Esto los obligaba a relacionarse con los mexicanos que se dedicaban a las mismas actividades.

En segundo lugar, el Casino fue creciendo en miembros y en actividades sociales. Las cifras de los primeros años me son desconocidas, pero para 1886 se contaba ya con 430 socios. A excepción de un par de años de crisis internas en los cuales el número descendió, la cantidad fue aumentando constantemente. Los locales que ocupó tenían que cambiarse continuamente ya que terminaban por ser pequeños e insuficientes para sus principales propósitos. Es importante mencionar que para la última década del siglo XIX las relaciones entre México y España eran diferentes a las del momento en que se había fundado el Casino. Éstas eran más estrechas, y las viejas rencillas posindependentistas parecían haber terminado. A esto contribuía también el gran número de espańoles que continuamente llegaba a México y la política de Díaz que apoyaba su inmigración. Por otro lado, lo consolidado del régimen, en cuanto a paz y estabilidad social y económica, favoreció a los empresarios españoles. De esta forma, las circunstancias del país, las de los socios más distinguidos del Casino y la de sus propios negocios forzó la socialización.

Los primeros ejemplos que encontré al respecto son aproximadamente de 1885. Primeramente, la Junta Directiva se molestó por un artículo escrito por el señor Muñiz, español socio del Casino, para el diario La Voz de España en que criticaba a México. Sus miembros se sintieron obligados a escribir una carta pública, "interpretando los sentimientos de la colonia", en contra del autor de dicho artículo, además de que acordaron "que el señor Muñiz sea borrado de la lista de socios del Casino hasta que dignamente se sincere de los cargos que públicamente se le han hecho." ${ }^{22}$ En 1888 apareció por primera vez la convocatoria para una suscripción para damnificados mexicanos por una inundación ocurrida en Guanajuato, y todos los miembros de la Junta Directiva accedieron a cooperar. ${ }^{23}$

Otro asunto significativo fueron los festejos del 16 de septiembre. La primera vez que se encuentra mención de ellos es en el año de 1883 , cuando el presidente del Casino informó en sesión directiva que una "comisión privada (de mexicanos) encargada de

\footnotetext{
${ }^{22}$ BACEM, Libros de Actas núm. 2, 18 de marzo de 1880 , f. $42 \mathrm{v}$.

${ }^{23}$ Ibid., junio de 1888 , fs. $59-59 v$.
} 
procurar que los festejos del 16 hallen eco en los individuos y corporaciones de todas nacionalidades" le había solicitado que el Casino adornara su fachada. La respuesta unánime fue en términos negativos. Para el año siguiente cambiaron de opinión, se decoró el Casino y asentaron que debería existir unión entre los españoles residentes y los mexicanos. ${ }^{24}$ Una noticia más al respecto fue de septiembre de 1885 , cuando se les invitó a participar con un carro alegórico para un desfile del día 16. La respuesta fue la siguiente:

La junta acordó que en las próximas festividades cívicas del mes de septiembre se adornen e iluminen los balcones del Casino $[\ldots]$ pero que no podrá accederse a los deseos de ustedes respecto a contribuir con un carro alegórico para el mayor lucimiento de las expresadas fiestas. ${ }^{25}$

Se dieron varias explicaciones, entre las cuales estaba que los estatutos del Casino prohibían distraer fondos de la sociedad para eventos de ese tipo, pero más importante fue que en

los momentos actuales, invadida como está la mayor parte del territorio patrio ${ }^{26}$ por el terrible azote del cólera [...] no son los más a propósito para despertar ninguna especie de regocijo en pechos españoles, tan atribulados en España como fuera de ella. ${ }^{27}$ $81 \mathrm{v}$.

${ }^{24} \mathrm{Ibid}, 8$ de septiembre de 1883 , fs. $72 v$. $y$

${ }^{25}$ Ibid., 4 de agosto de 1885 , fs. $4 \mathrm{v} .-5$.

${ }^{26}$ Siempre que los españoles socios del $\mathrm{Ca}$ sino se referian a España lo hacían como el "territorio patrio" o "la patria", tal es el caso en esta cita.

${ }^{27}$ Ibid.
Así, la elite de la colonia comenzaba un esfuerzo por socializar con los mexicanos, sobre todo con los que compartían ciertos intereses. Por lo mismo resultaba importante también quedar bien con los organizadores de los festejos y con las autoridades de la ciudad, sobre todo en una festividad tan importante. Poco a poco se fueron abriendo más y más, como se irá viendo, aunque nunca dejaron a un lado la relación con España y ésta siempre ocupó el lugar más importante.

Durante la última década del siglo XIX el Casino cambió en muchos otros aspectos. Como vimos, el número de socios había ido en aumento. También se habló de unos años de crisis en los cuales el número de socios bajó hasta 198 al iniciarse 1893. Esto se debió a diversas causas, entre ellas que las Juntas Directivas de estos años fueron acusadas por no esforzarse en convocar a los españoles para que ingresaran al Casino. Por otro lado, se puede inferir a través de discusiones en las sesiones de la Junta, que existían diferencias internas, tal vez por cuestiones económicas en México o por políticas de España, que hicieron que muchos socios se quisieran retirar del Casino.

La Junta Directiva electa en 1893 se propuso iniciar una renovación en diversos aspectos y uno de los principales fue el de elevar el número de socios. Convocó a una verdadera cruzada para que cada uno de los miembros existentes reclutara la mayor cantidad posible de españoles. Así al finalizar el año contaban con 562 socios y a partir de este momento el número aumentó cada año, siendo 


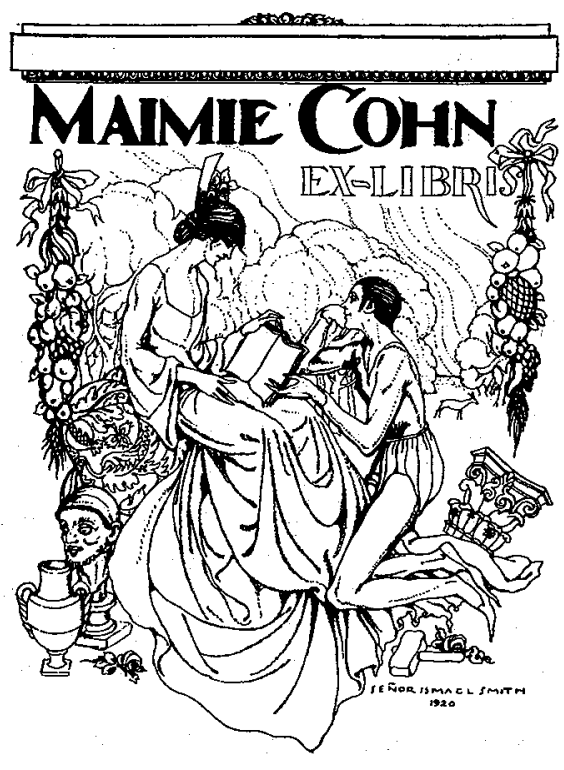

más considerable entre 1909 y 1915 . Poco tiempo antes se había aprobado un nuevo reglamento, que tenía el propósito de incrementar el capital para mejorar las instalaciones y de ser posible adquirir un local. ${ }^{28}$ Esta idea no se desechó y finalmente consiguieron su propia casa en 1903. Diez años antes, en 1893, sólo les había sido posible rentar una nueva casa, más amplia y sobre todo, más acorde al estatus que según consideraban, tenían ya dentro de la sociedad mexicana.

Fue también durante esta década cuando los presidentes del Casino comenzaron a preocuparse por quienes asistían a sus reuniones y fiestas así

${ }^{28}$ BACEM, Libros de Actas núm. 3, abril de 1891 , fs. $15-15 v$. como a los salones de juego. En una sesión se dijo que estaban preocupados porque la gente que iba al Casino no era la apropiada ni aquéllas con la que deseaban convivir, además de que no los hacía estimables ante la sociedad mexicana. Así, aparte de reclutar a los nuevos socios, decidieron abrir sus puertas a lo más selecto de la burguesía mexicana. La alta sociedad capitalina comenzó a ser invitada a fiestas, tertulias, y bailes, y además se extendieron pases de visita para que un español pudiera tener un invitado durante un tiempo determinado, siempre y cuando éste fuera aprobado por la Junta Directiva.

En esta época fueron personajes importantes del Casino Antonio Basagoiti, creador de la fundidora de Monterrey, entre otras empresas; Delfín Sánchez, Telésforo García, Saturnino A. Sauto, Juan Llamedo, prominentes hombres de negocios que realmente comenzaron a cambiar la fisonomía de la sociedad. Por un lado, ya como anotamos antes, empezó a producirse una socialización con la burguesía mexicana por medio de fiestas y bailes, y un intento por ampliar y embellecer el Casino; por otro, el hecho de acercarse y simpatizar con las autoridades del país significó un deseo de aproximación a la clase política porfiriana para obtener favores, concesiones o simplemente respeto y buen trato para sus negocios. ${ }^{29}$

${ }^{29}$ Esta última aseveración la hago sin fundamentos específicos, sin embargo, es la época en que los negocios de estos españoles realmente están floreciendo y en que es notorio el acercamiento a la alta burguesía y la clase 
Leonor Ludlow afirma que el enriquecimiento de un sector de la inmigración, dentro del cual se encuentran los nombres antes mencionados,

favoreció la movilidad ascendente, y parte de los recursos del comercio les permitió establecer relaciones de interés con los grupos políticos domịnantes. ${ }^{30}$

Esta posición fue utilizada también para no perder lazos con España y mantenerse relacionados con aspectos económicos y políticos de la península. Esto fue evidente en diversos casos, pero tal vez el más notorio fue el conflicto por la independencia de Cuba entre 1895 y 1898 . El Casino se mostró abiertamente del lado de España en cuanto a oponerse a otorgar la independencia a la isla. Los socios llevaron a cabo diversas actividades y entre ellas, como era ya costumbre, organizaron en 1895 una suscripción para el ejército español. El semanario $\boldsymbol{E l}$ Mundo Ilustrado publicó al respecto:

Como ya se dijo, a raíz de la Gran Asamblea celebrada por la colonia española en su Casino, uno de los miembros de esta colonia telegrafió al señor general Martínez Campos preguntándole qué era lo que más necesitaba para la campaña contra los insurrectos, y el general respondió que caballos para tropa,

política mexicana. Alguna intención había y no habría de ser puramente social, aunque ésta era también importante. El reconocimiento y agradecimiento al gobierno de Díaz era amplio entre toda la colonia española, la elite de la misma lo sentía también y podía expresarlo por estos medios.

${ }^{30}$ Ludlow, "Empresarios", 1994, p. 167.

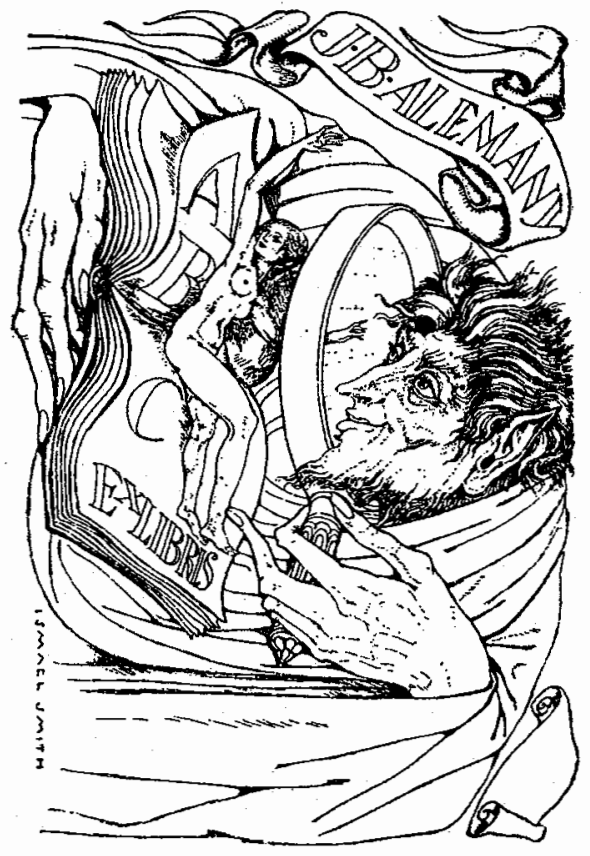

y con especialidad mulas. Los numerosos españoles que componen la repetida colonia se suscribieron [es decir aportaron dinero, se habla aquí de una suscripción como las ya antes mencionadas] para atender a las necesidades del ejército que en la isla lucha con los insurrectos, y el órgano de aquellos ha abierto en sus columnas un registro para los que inscribirse quieran como voluntarios. $^{31}$

Además, cancelaron fiestas como la de la Covadonga del año de 1896 la cual "se reducirá a un sermón, enviando a Cuba el dinero que se iba a em-

31 "Sobre el Casino Español. Una suscripción para Cuba", El Mundo Ilustrado, 13 de octubre de 1895, p. 13. 
plear en los festejos." ${ }^{.32}$ En las actas de los años de conflicto se habló constantemente de que esperaban una pronta solución favorable a la patria, "por la integridad del territorio y el honor de España". ${ }^{33}$ Por lo que aparece en las actas, no querían que fuera muy evidente la cantidad de dinero que se había reunido para la guerra en Cuba ni cómo se le iba a proporcionar al ejército español. Durante los años de la guerra y poco después del llamado a la suscripción, Antonio Basagoiti salió rumbo a Europa, según lo que se dijo, por un asunto familiar. Al parecer, hizo una escala en Cuba para entregar el dinero a los españoles, y se convirtió así en una especie de contacto entre la alta esfera de la colonia española en México y el ejército español en Cuba. Seguramente existía alguna relación con el gobierno espanol directamente o a través de la legación en México, ya que en España, una vez terminada la guerra, se le quiso recompensar con un título nobiliario que no aceptó. ${ }^{34}$

\section{LA ÉPOCA DE LA CONSOUDACIÓN}

Esta etapa de apertura del Casino Español no fue meramente casual sino que correspondió a una época de auge y predominio de lo extranjero en México. La estabilidad económica y polí-

\footnotetext{
" 32 "Noticias sobre España y Cuba", El Mundo Ilustrado, 21 de junio de 1896, p. 379.

${ }^{33}$ BACEM, Libros de Actas núm. 4, diciembre de 1895, p. 9.

${ }^{34}$ Esta información me fue proporcionada por Ángel O'Doherty, director del BACEM.
}

tica del régimen porfirista había dado prosperidad al país, además de que los largos años de paz significaron confianza para los inversionistas, tanto nacionales como extranjeros. Los últimos años del siglo XIX vieron también la influencia de las ideas positivistas que permearon a la política, a la economía y a la sociedad en su conjunto, tanto por su ideología, como por sus formas de actuar. Los máximos representantes de estas teorías e ideas inculcaron en la alta burguesía un deseo de ver a México como un igual entre las grandes potencias europeas y Estados Unidos.

Así los extranjeros en México, tanto las colonias como los diplomáticos y sus familias, se convirtieron en un modelo a seguir para la sociedad mexicana. La minoría que conformaban los miembros de colonias como la alemana, francesa, española, inglesa y americana era la representación de aquello en que debía conformarse la burguesía mexicana. Eran ellos con sus industrias y comercios, además de bancos y fábricas, los que ayudarían al desarrollo económico.

A través de sus actividades, estos extranjeros marcaron pautas sociales, gustos, modas, lugares distinguidos y favoritos de reunión, diversiones, etc. La visita a sus centros y la participación en sus actividades económicas fueron la conducta que los mexicanos adoptaron para incorporarse al estilo de vida de estas naciones. ${ }^{35}$ Asimismo, el hecho de visitar las casas y residencias oficiales de los extranjeros era una muestra de estatus; la burguesía mexi-

${ }^{35}$ Beezeley, Judas, 1987, p. 13. 
cana se sentía reconocida, por ejemplo, si se le invitaba a reuniones o fiestas como las que había en las legaciones para celebrar fechas importantes de cada país. Junto a las residencias diplomáticas, el otro punto importante de reunión fueron los casinos de los diferentes países; además del español, estaban el Casino Alemán, el Casino Francés y el Casino Inglés, así como el Club Americano y el University Club. ${ }^{36}$ Todos ellos se habían ido formando a lo largo del siglo XIX, unos antes que otros y algunos con mucho más éxito entre los miembros de la burguesía mexicana y de la elite extranjera. ${ }^{37}$ Para algunas de estas colonias la relación con sus representantes diplomáticos era muy importante y las fiestas para conmemorar fechas significativas de sus países se hacían en la legación o eran organizadas por sus ministros; a ellas asistía la elite de cada una de las colonias, así como invitados especiales entre los demás extranjeros y "lo mejor" de la sociedad mexicana. ${ }^{38}$

${ }^{36}$ Tavares, Colonia, 1995, p. 21.

${ }^{37}$ Realmente hay muy poca literatura sobre estos centros. Sobre el propio Casino Español no existe una monografía, así como tampoco sobre las de otros centros de españoles en México. Sobre las otras organizaciones extranjeras no encontré nada específico, tan sólo referencias en otro tipo de obras: Beezeley, Judas, 1987; Genin, Français, 1931; González, Extranjeros, 1994; Oeste de Bopp, Contribución, 1991.

${ }^{38}$ Varios reportajes sobre estos sucesos, con amplias descripciones, se pueden encontrar en El Mundo Ilustrado, El Diario Ilustrado, Arte y Letras, publicaciones semanales de finales del porfiriato de las cuales se consultaron los años entre 1890 y 1910 . En estas revistas es evidente el modelo de lo extranjero para la burguesía mexicana.
En la última década del siglo XIX y la primera del siglo $x x$ parece que el centro más importante era el Jockey Club, sociedad mexicana creada de acuerdo a los modelos de las extranjeras. Un segundo lugar lo ocupaban el University Club y el Casino Español. Cada uno de ellos tenía un papel diferente que cumplir, lo mismo que las colonias de sus respectivos países. Por ejemplo, los estadunidenses en México estuvieron siempre muy cerca de su embajada, y su ministro era realmente la autoridad máxima, el verdadero representante de su país. En cambio, para los españoles, sobre todo para los miembros de la elite que formó el Casino Español, la legación y el ministro no ocupaban un lugar tan importante. Nunca se sintieron comprometidos a fraternizar con-él y en ocasiones estuvieron abierta y públicamente en su contra. ${ }^{39}$

Para este momento, en el Casino se advierte una sociedad fuerte, segura y bien consolidada. Sus socios exteriorizaban la idea de que para ellos lo más importante era continuar con sus negocios personales de manera exitosa, y para ello necesitaban presentarse ante la sociedad mexicana como un grupo privilegiado. Por lo mismo, su interés político no giró en torno de la colonia

\footnotetext{
${ }^{39}$ En 1897 en un banquete ofrecido por el Casino, se dio un enfrentamiento entre el español Ignacio Noriega y el ministro Becerra Armesto. Después de largas discusiones de la Junta Directiva se acordó no aceptar más al ministro dentro del Casino por haber insultado $y$ ofendido a miembros de la sociedad. En represalia, 55 socios renuncian. La Junta Directiva no cambió su resolución y al parecer se sintió segura. BACEM, Libros de Actas núm. 2, 1897.
} 
española, ni de las autoridades llegadas desde España; estaba más bien encaminado a relacionarse con la alta burguesía mexicana y posteriormente, con la clase política. La propia Junta Directiva dijo al respecto en 1896 :

Uno de los cuidados principales que ha tenido la Junta ha sido el de cultivar las cordiales relaciones que esta sociedad mantiene con las autoridades de la nación, por eso no ha perdonado medio alguno que le permitiera resaltar el respeto y simpatía que la colonia española siente hacia ellas, y muy especialmente hacia el $[\ldots]$ señor presidente de la República cuya noble conducta respecto a la madre patria viene siendo notoriamente amigable y cariñosa. ${ }^{40}$

Como miembros prominentes de la colonia española muchos de los socios del Casino aparecían constantemente en los diarios de la capital y en los semanarios de tipo social. Se reseñaban las fiestas de la Covadonga, las actividades de la Beneficencia Española y las fiestas del Casino Español. Por ejemplo, en octubre de 1902 apareció un artículo en $E l$ Mundo Ilustrado acerca de las fiestas de la Covadonga que dice así:

siguiendo una costumbre establecida la junta de Covadonga organizó esta vez el banquete que los españoles celebran año con año, pasadas las fiestas del 8 de septiembre (día de la Virgen). ${ }^{41}$

40 BACEM, Libros de Actas núm. 4, diciembre de 1896 , f. 30 .

41 "El banquete de los españoles", El Mundo Ilustrado, año IX, tomo II, núm. 14, 5 de octubre de 1902.
Sobre el mismo tema, esta fiesta española se celebró en 1906 con la presencia del presidente Díaz y el vicepresidente Ramón Corral. La Junta del Casino se unió a la de Covadonga para recibir a las autoridades. ${ }^{42}$

En los libros de actas se pueden encontrar diversas muestras de que los socios del Casino que eran electos miembros de la Junta Directiva eran los más favorecidos económicamente, los que más influencia tenían por sus propios negocios o por ser reconocidos socialmente. Hasta los primeros años de este siglo, la economía interna de la sociedad no era precisamente floreciente. ${ }^{43}$ Casi todos los años, los miembros de la Junta tenían que aportar cantidades de sus bolsillos para que las cuentas terminaran en números negros. Esto muestra que disponían de los medios para hacerlo y que realmente les interesaba que el Casino siguiera en pie. En ocasiones, a las actas de las sesiones se agregaban listas de suscripciones, sobre todo en el caso de demandas que realmente se consideraban primordiales. Los nombres de los miembros de las juntas encabezaban estas listas junto con los de residentes importantes que eran

${ }^{42}$ BACEM, Libros de Actas núm. 6, 4 de septiembre de 1906, f. 9v.

${ }^{43}$ No quiero decir que después se haya convertido el Casino Español en una asociación rica, nunca ha tenido mucho dinero ya que su política ha sido cobrar pocas cuotas y el dinero utilizarlo en mejoras del propio inmueble. Cuando han necesitado dinero para algo extraordinario, como fiestas o banquetes, se organizan las suscripciones. Información proporcionada por Ángel O'Dogherty. 
simplemente socios. ${ }^{44}$ Con estos nombres aparecían las cantidades más altas, y generalmente muy por encima de aquéllas de la mayoría de los socios.

Así las cosas, en esta etapa, se advierte que el Casino estaba en manos de un círculo pequeño. Las mismas personas se turnaban en los puestoos importantes: presidente, vocales, $y$ suplentes, y conformaron de esta manera, una elite dentro de la elite. Algunos de los hombres a los que nos referimos son Antonio Basagoiti, que ya mencionamos como dueño de la Fundidora Monterrey y la Compañía Tabacalera. Este exitoso vasco estuvo en los altos puestos del Banco Nacional de México, la institución bancaria más poderosa de la época; Cerruti afirma que "todavía en 1909 figuraba como componente del consejo de administración". Además, participó con Íñigo Noriega en tres grandes proyectos: la Compañía Industrial de Hilados, Tejidos y Estampados San Antonio Abad S. A., la Negociación Agrícola Xico y Compañía S. A. y la Compañía Industrial de Atlixco S. A. ${ }^{45}$ Otro de ellos fue Adolfo Prieto, que trabajó con el anterior director de la Fundidora ${ }^{46}$ además de haber sido socio fundador y presidente del Banco Hispanoamericano. ${ }^{47}$ La familia Noriega, cuyo miembro más conocido fue Íñigo Noriega, estuvo en las altas esferas del Casino y fue fun-

44 Tal es el caso de f́nigo Noriega que a pesar de su posición económica y su influencia sobre la colonia, nunca perteneció a las juntas directivas del Casino.

${ }^{45}$ Cerutti, Empresarios, 1995, p. 117. Ludlow, "Empresarios", 1994, p. 158.

${ }^{46}$ Carreño, Españoles; 1942, pp. 250-251.

${ }^{47}$ Cerutti, Empresarios, 1995, p. 117. dadora y directora de diversas empresas algodoneras, textileras, etc. Delfín Sánchez Ramos fue otro exitoso español quien se casó con una hija de Benito Juárez y construyó, entre otras cosas, el ferrocarril de Morelos; ${ }^{48}$ su hijo Andrés Sánchez Juárez se casó con una hija del licenciado Ramón Corona. ${ }^{49}$ Telésforo García fue un distinguido miembro de la elite cultural e intelectual. Una nota curiosa acerca de este personaje es del año de 1895, y dice que obtuvo mención honorífica en la competencia de carruajes adornados celebrada el 16 de septiembre con motivo de las fiestas de independencia ${ }^{50}$ Esto da muestra de la relación que existía con la elite mexicana, ya que era ésta última la que participaba en dichos eventos. Telésforo García también perteneció a la Camara de Comercio, "una de las instituciones clave de la inmigración española en la segunda mitad del porfiriato", ${ }^{51}$ en la cual se reunían los empresarios y comerciantes españoles más prósperos. Junto con él estaban también en el Casino, Casimiro Collado, Francisco Ma. Prida y Ricardo Sainz, textilero que trabajaba desde la capital; además figuraban Antonio Basagoiti, Saturnino Sauto, accionista del Banco Mercantil Mexicano en 1882 y posteriormente consejero del Banco Nacional, así como de las industrias algodoneras de la Laguna, y los hermanos Juan

48 "Don Delfín Sánchez Ramos", El Mundo Ilustrado, tomo II, núm. 10, 4 de septiembre de 1898 , p. 188.

49 El Mundo Ilustrado, 24 de mayo de 1903.

${ }^{30}$ Ibid., 22 de septiembre de 1895.

${ }^{51}$ Cerutti, Empresarios, 1995, p. 100. 
y Delfín Sánchez Ramos, etc..$^{52}$ Por su parte, don Valentín Elcoro, también presidente del Casino Español, tenía un almacén de fierro, ferretería, mercería y maquinaria. ${ }^{53}$ Además, varios españoles socios del Casino y miembros todos de la junta directiva en algún tiempo, se dedicaron a la industria de hilados y tejidos de lana y de algodón en la zona de Puebla y el Distrito Federal, "dejando instalaciones modelos como El Carmen y La Constancia, La Colmena y Miraflores", etc. ${ }^{54}$ Leticia Gamboa en sus estudios sobre la industria textil en Puebla habla acer. ca del grupo, económica y socialmente poderoso que los españoles textileros formaron en esa región. Algunos de ellos, o sus familiares cercanos, vivían en el Distrito Federal y pertenecieron al Casino Español; tal es el caso de la familia Rivero Quijano y Sánchez Gavito. ${ }^{55}$ Muchos de estos hombres también fueron directivos de la Beneficencia Española, como lo dice Alberto María Carreño y da el caso de Adolfo Prieto y José Sainz durante 1909, mismo año en que el señor Prieto dejó la presidencia del Casino. ${ }^{56}$

Queda claro, entonces, que el manejo de las asociaciones más grandes e importantes de españoles durante esta época estuvo en muy pocas manos, las cuales se reconocían unas a otras como miembros del mismo grupo privilegiado.

${ }^{52}$ Ludlow, "Empresarios", 1994, p. 144.

${ }^{53}$ El Correo Español, año Xxi, núm. 6081, 26 de marzo de 1910.

${ }_{54}$ Carreño, Españoles, 1942, pp. 250-251.

ss Gamboa, Empresarios, 1985, p. 180.

${ }^{56}$ Carreño, Españoles, 1942, p. 254.

\section{COMIENZA LA RELACIÓN}

CON EL GOBIERNO

El punto más significativo de la relación de este grupo de la colonia española con la elite mexicana se dio al vincularse con el propio presidente Porfirio Díaz. He mencionado ya que el dictador favoreció ampliamente la inmigración extranjera a México aunque nunca logró los resultados que deseaba, y que en el país se vivía bajo una atmósfera de predilección por lo extranjero, sobre todo entre la alta burguesía. Así, combinando los buenos ojos con que el presidente veía a sociedades como el Casino Español y sus miembros, eran los intereses de éstos con los que estaban sentadas las bases para una relación próspera y fructífera.

Como toda unión intrapersonal, ésta fue alcanzando niveles cada vez más altos. Para principios del siglo en las actas del Casino, encontré que cada enero se enviaba una felicitación al presidente por el comienzo del año, y se registraba también la respuesta de éste. Después, el saludo no era solamente por esta festividad sino se le sumó también el 15 de septiembre, cumpleaños del dictador. ${ }^{57}$ El siguiente paso, y que habla ya de un verdadero interés de la gente del Casino por moverse dentro del círculo de la alta política mexicana, fue invitar al presidente a una fiesta en la sede de la institución, en la calle de Isabel la Católica. ${ }^{58}$

${ }^{57}$ BACEM, Libros de Actas núm. 5, 18 de octubre de 1905 , f. $78 \mathrm{v}$.

${ }^{58}$ No se han mencionado los locales en que se encontraba situada la sociedad. Éstos fueron 
La primera ocasión en que el presidente Díaz puso pie en el Casino Español fue con motivo del nacimiento del Príncipe de Asturias en 1907, cuando "la colonia española había acordado celebrar con el mayor entusiasmo el día". La fecha fijada fue el 8 de septiembre $y$

entre los invitados de honor, figuraban los señores presidente de la república, secretarios de estado, embajador de Estados Unidos y ministros plenipotenciarios acreditados en nuestro país, los miembros más distinguidos de la colonia y numerosas familias y caballeros de nuestros altos círculos sociales. ${ }^{59}$

A los dos años dieron un paso aún mayor. El presidente en turno,

el señor [José] Sánchez Ramos expresó a la junta un proyecto de celebrar en el

varios, $y$ todos alquilados, durante las primeras décadas. Después de muchos intentos y contratiempos se logró comprar un terreno en el número 11-2 de la calle del Espíritu Santo, hoy número 12 de Isabel la Católica, $y$ en el año de 1903 se terminó la construcción del local donde actualmente reside el Casino Español. El proyecto arquitectónico concibió una casa verdaderamente suntuosa, construida por un ingeniero español, Emilio González del Campo, en estilo renacentista español. Parecería que con este proyecto se hubiera querido recordar y tener presente a lo que consideraban como el mejor exponente de España, la época que más gloria le había dado al país, $y$ presentarse ante la sociedad mexicana como tal. El salón del piso superior, llamado de los Reyes, solicitado hasta la fecha para grandes eventos, está dominado por dos enormes retratos: el del rey Alfonso XII y el de su madre Isabel II.

59 "En el Casino Español", El Mundo Ilustrado, año XIV, tomo Y, núm. 23,9 de junio de 1907. próximo 9 de abril dos grandes fiestas, un baile y un banquete en honor del señor presidente de la república y de su digna esposa, proyecto que fue aprobado unánimemente por la junta. ${ }^{60}$

De esta forma, el Casino Español alcanzó su máximo nivel de acercamiento a grupos políticos poderosos. El asunto relatado no terminó con la sola fiesta. Un mes después del banquete Sánchez Ramos propuso

obsequiar a la señora del presidente de la república, con motivo del día de su santo, con dos cuadros pintados al óleo, representando vistas del Casino durante las fiestas últimas. ${ }^{61}$

El hecho de relacionarse con las altas esferas de la política no significó que los españoles se hubieran entrometido en la política mexicana de finales del porfiriato, sino que hizo evidente que a través del Casino buscaron favores y prerrogativas de la alta jerarquía nacional. No sólo se ofrecieron fiestas y bailes para el presidente sino que se hicieron también para políticos como Ramón Corral, vicepresidente de la república, además de que los miembros del gabinete eran invitados constantemente a reuniones y a los salones de juego.

La relación fue estrecha también con miembros del cuerpo diplomático acreditado; por ejemplo, en 1906 la Junta Directiva acordó hacer socio honorario del Casino al ministro británi-

\footnotetext{
${ }^{60}$ BACEM, Libros de Actas núm. 6, 16 de enero de 1909 , f. 41.

${ }^{61}$ Ibid., 22 de mayo de 1909, f. 44
} 
$\operatorname{co.}^{62} \mathrm{La}$ idea la puede resumir una carta del ministro de España en México, Bernardo de Cólogan y Cólogan, donde manifestó

que los señores representantes diplomáticos extranjeros le habían hecho grandes elogios y felicitaciones por las fiestas dadas en el Casino en honor'del señor presidente de la república y su honorable señora y que había informado de ello al señor ministro de Estado, quien le transmitió una Real Orden diciendo haberse enterado con interés y satisfacción del gran éxito de las fiestas dadas en el Casino. ${ }^{63}$

Por lo relatado hasta el momento, se puede afirmar que el Casino Espa* nool alcanzó su máximo esplendor hacia el final de la primera década del siglo xx y se podría decir que cerró este ciclo ascendente con su participación en 1910 en las fiestas del Centenario de la Independencia. Estos festejos fueron el regalo que Díaz dio al mundo para mostrar a México, para enseñar al resto de las naciones que el país se había modernizado y que estaba a la altura de cualquier país desarrollado. El Casino no se podía quedar atrás desaprovechando esa oportunidad.

Desde la última vez que, en 1883 , los miembros de la junta directiva se habían negado a adornar sus balcones para la celebración del 16 de septiembre, hasta este momento en 1910 , muchos factores habían concurrido para que la actitud de los españoles fuera la contraria. Un año antes, dicha colonia se organizó para crear un co-

${ }^{62}$ Ibid., diciembre de 1907, f. $39 \mathrm{v}$.

${ }^{63}$ Ibid., 25 de julio de 1909, f. 45. mité especial encargado de formar un proyecto para participar en los festejos del Centenario. Así, José Sánchez Ramos propuso a los señores José Sainz y José Visoso para que formaran parte de la comisión española. ${ }^{64}$ La siguiente nota al respecto es de 1910 y el Casino Español pasó de proponer representantes a la comisión, a ser la sede de la misma. En abril se reunió bajo la presidencia de Sánchez Ramos y al respecto el Correo Español publicó:

Entre los reunidos reinó el mayor entusiasmo y los más laudables propósitos, a fin de que los españoles aquí residentes unidos estrechamente en una única aspiración y en un solo ideal, contribuyamos con nuestro concurso a la animación y al regocijo patriótico de este hermoso y hospitalario país, mediante una sincera y magnífica manifestación de confraternidad con sus hijos. ${ }^{65}$

Creo que la cita anterior habla por sí sola y es evidente el grado de seriedad con que los españoles del Casino consideraron las fiestas del centenario. Conforme avanzaron los preparativos, se decidió cuál iba a ser el papel específico de la sociedad. Otra cita de los libros de actas es sumamente clara al respecto:

El señor presidente da a conocer un proyecto de fiestas con que a su juicio el Casino debe obsequiar en el mes de septiembre al seńor presidente de la república, a su señora esposa, y a los miembros de la misión extraordinaria española que vengan con motivo del

${ }^{64}$ Ibid., 14 de noviembre de 1909, f, 48.

6s "España en México", El Correo Español, año XxI, núm. 6108,15 de abril de 1910. 
centenario. Este proyecto que consiste en un banquete seguido de baile, merece la aprobación de la Junta, la que autoriza al señor presidente para que lo lleve a cabo con todo el esplendor que sea posible.

Habría que resaltar también el hecho de que por la redacción, y por lò que expongo a continuación, parecería que el propósito de José Sánchez Ramos era muy personal. Nunca aparece una opinión contraria de parte del resto de la Junta Directiva ni propuestas que resultaran negativas; mucho menos se trató de lo que pensaba la mayoría de los socios del Casino. Seguramente Sánchez Ramos, por su posición como hombre de negocios y por la cercanía de su familia al gobierno desde tiempos de Benito Juárez, determinó que sus palabras pesaran y que pudiera pertenecer al alto círculo de las influencias políticas. Carlos Illades dice sobre él que era hombre de confianza de Díaz, ${ }^{66}$ aunque no encontré nada que corroborara esta información.

La segunda parte de la cita dice lo siguiente:

Como para llevar a cabo los festejos que quedan mencionados no contará el Casino con el dinero suficiente, la Junta autoriza ampliamente al señor presidente para que a nombre de la sociedad gestione en caso necesario y consiga un préstamo por la cantidad que se precisa, con garantía del mis no Casino. $^{67}$

${ }^{66}$ Illades, México, 1985, p. 11.

${ }^{67}$ BACEM, Libros de Actas núm. 6, 14 de julio de 1910 , f. 54 .
La fiesta del Casino fue el 28 de septiembre y dos días después se hizo otra para la delegación especial de España encabezada por el marqués de Polavieja. Ambas tuvieron un éxito enorme y de esta forma José Sánchez Ramos coronó su presidencia en el Casino, y éste su presencia dentro de lo más alto de la sociedad mexicana. El banquete y el baile se reseñaron en los diarios y revistas que se han mencionado y fueron la muestra palpable del acercamiento que existía entre esta elite española y el régimen del general Díaz.

LOS ESPAÑOLES Y IA REVOLUCIÓN:

POLITICA Y DIPLOMACIA

Esta actitud de los españoles podría conducir a pensar que no apoyaron el movimiento revolucionario de 1910 . En general, aunque se mantuvieron alejados de la política mexicana, por lo numeroso de la colonia, era muy difícil que contemplaran el conflicto armado sin reacción alguna, sobre todo cuando los enfrentamientos afectaron sus intereses personales y económicos. Así, la mayor parte de la colonia española se mantuvo fiel a Díaz y se mostró contraria a Madero, hecho que fue más notorio entre los hombres más prominentes, como fueron los miembros del Casino. El haber hecho pública esta posición dio como resultado que al paso de los primeros ańos de la revolución ésta les fuera poco favorecedora. El propio ministro español, Bernardo de Cólogan y Cólogan, que estaba a cargo de la legación desde 1907, compartía estas ideas, 
pertenecía al grupo que al principio confiaba plenamente en que la revolución no prosperaría: no reconocía ningún mérito personal a Madero, ni creía tampoco que el movimiento pudiera salir adelante sin contar-como no contaba- con jefes militares reconocidos. ${ }^{68}$

Sin embargo, el fondo de las opiniones era distinto. Para los empresarios e industriales españoles el problema se reducía a no aceptar la caída de un presidente que había creado todo un régimen político altamente favorecedor; el no admitir a Madero podía ser incluso personal. González Loscertales dice al respecto:

otro testimonio [...] concede a Madero los calificativos de enardecido y poseído de su papel de candidato a la presidencia que resultaban a los distinguidos socios del Casino Español de México, bastante ridículos, en un hombre que no tenía la menor posibilidad de convertirse en presidente. ${ }^{69}$

Por su parte, a medida que se desarrollaban los acontecimientos, Cólogan apoyó la legalidad del gobierno mexicano, tal como lo hizo siempre hasta que se retiró de México en 1914. Él estaba consciente de que Díaz había apoyado a los miembros de su colonia y había favorecido las relaciones con España, sin embargo, sabía que su papel era mantenerse fuera de los conflictos políticos mexicanos y manifestarse a favor de cualquier go-

\footnotetext{
${ }^{6 *}$ MacGregor, España, 1992, p. 84.

${ }^{69}$ González, "Colonia", 1977, p. 343.
}

bierno que estuviera legalmente establecido. ${ }^{70}$ Esta diferencia de opiniones se hizo evidente en el momento de la caída de Madero e hizo incluso que los miembros del Casino Español se enfrentaran con el ministro. Cólogan trató de defender a los residentes españoles y les quiso hacer notar que su abierta oposición a Madero podría traerles graves consecuencias. Más adelante se verán algunos hechos que acabaron por comprobar esto. Pero muchos españoles no lo vieron así, llegando incluso a pensar que Cólogan estaba en contra de ellos.

A pesar de no creer que Madero pudiera triunfar, los españoles presintieron graves conflictos e incluso comenzaron a sufrirlos, aunque más en otras regiones del país que en la capital. Sin embargo, es significativo que en las actas de la Junta Directiva del Casino no se haya mencionado nada al respecto. En las sesiones de fechas cercanas a la salida de Díaz y a la llegada de Madero se trataron solamente cuestiones internas de la sociedad y no se mencionaron los conflictos mexicanos. Seguramente no es que no se hubieran discutido, sino que más bien se acordó no integrarlos en los libros. Lo primero que aparece en las actas acerca de Madero y su gobierno es una propuesta para organizar un baile por la paz, que "acordó celebrarse por medio de un convite en honor del señor presidente de la república y al que serán invitados los principales colaboradores de su gestión adminis-

\footnotetext{
${ }^{70}$ Esta actitud de Cólogan es muy clara en el libro de MacGregor, España, 1992.
} 
trativa." 11 No hay noticia de que Madero haya asistido al banquete.

A pesar de que la actitud de los miembros del Casino no está totalmente clara a través de los documentos, sí se pueden deducir ciertos comportamientos e ideas. El Casino cambió radicalmente hacia el gobierno mexicano, hacia el resto de la colonia e incluso hacia las demás colonias extranjeras. Bajo las circunstancias revolucionarias sí se preocuparon de lo que los miembros de otras colonias hicieron o dijeron. Por ejemplo, en diciembre de 1911 les llegó un comunicado de un grupo llamado "Club Político Ejército Libertador" en que solicitan su cooperación para hacer un obsequio a Madero. Antes de responderle los miembros de la Junta decidieron "informarse si las demás colonias extranjeras han recibido la misma invitación y cuál ha sido su actitud en el asunto." 72 Otra prueba significativa es una nota del presidente del Casino en la que agradece al Club Británico el que se le haya nombrado miembro honorario de dicha asociación. ${ }^{73}$

El Casino también se acercó al resto de las colonias extranjeras con el propósito de organizar ayuda para los residentes en México; la Junta Directiva lo decidió así "para la defensa de las personas e intereses en el caso de que las

${ }^{71}$ BACEM, Libros de Actas núm. 6, 28 de junio de 1911, f. $69 \mathrm{v}$.

${ }^{72}$ Ibid., 10 de diciembre de 1911, f. 82 . Respecto al grupo político no se encontró información alguna, por información proporcionada por la doctora Josefina MacGregor parece que es un grupo que pretendía acercarse a los zapatistas.

${ }^{73}$ Ibid., 11 de enero de 1912, f. $85 v$. circunstancias lo requieran. ${ }^{74}$ La ủnión no fue sólo con este grupo sino también con los otros centros de españoles que existían en la época. Por ejemplo, para la toma de posesión de Madero se invitó a una reunión especial:

con este motivo el señor presidente del Casino Español convocó a los presidentes de los demás centros y sociedades españolas de esa capital para comunicarles los deseos de las autoridades arriba mencionadas a obrar en este sentido mancomunadamente para representar así mejor a todos los elementos que forman la colonia española. ${ }^{75}$

En la época de Díaz los miembros del Casino aprovechaban cualquier cosa para una buena relación con el presidente y con el gobierno mexicano; y si podían hacerlo solos, es decir, que en tal evento sólo apareciera el nombre del Casino Español, mucho mejor. Durante el régimen maderista la actitud fue diferente. Sólo encontré dos actos organizados por el Casino en que estuvieran invitados el presidente y sus ministros. El primero es una función de teatro a la que se invitaría al ministro español, al presidente de la república y a los secretarios de estado, acompañados de sus familias. El segundo es una fiesta que el Casino decidió organizar para Madero. El tono sobre la descripción de la organización muestra que lo hicieron un tanto forzados, pero tal vez lo más notorio es que no quisieron llevar a cabo la fiesta en los salones del Casino

${ }^{74}$ Ibid., 7 de marzo de 1912, f. 93.

75 Ibid., 17 de octubre de 1911, f. 77 . 
y prefirieron un lugar público. Además, buscaron realizarla entre todos los centros españoles y no aportar un solo peso de las arcas del Casino; además, sostuvieron, que si abrían una suscripción para tal efecto sería un fracaso. Esta actitud tan evidentemente contraria a Madero y su gobierno se acompañó con un cierto apoyo a Félix Díaz y posteriormente al general Huerta. Loscertales dice que los españoles estaban contrariados por los sucesos revolucionarios, ya que se habían visto afectados directamente, y que además creían que el general Díaz "los adoraba y que por lo tanto, lo mismo haría su sobrino". ${ }^{76}$

La Decena Trágica en febrero de 1913 resultó ser definitiva para el desarrollo de los acontecimientos en torno al Casino Español durante los dos años siguientes. Al igual que durante la caída de Díaz, en las actas de las sesiones de la Junta Directiva no se habló de los sucesos políticos. Al parecer, durante los aciagos días de febrero la casa de Isabel la Católica no cerró sus puertas un solo día, solamente suspendió un té programado para el día $21 .{ }^{77}$ Sin embargo, sucedieron cosas que habrían de afectar la relación del ministro Cólogan con el Casino y que evidenciarían que los propósitos y los puntos de vista de cada uno sobre la Revolución Mexicana eran distintos.

El día 9 de febrero, tras una entrevista de Cólogan con el ministro Lascurain se enteraron que el general Huerta estaba ya al mando de las tropas fe-

${ }^{76}$ González, "Colonia", 1977, p. 362.

${ }^{77}$ El Correo Español, viernes 21 de febrero de 1913, año XXYv, núm. 6773. derales en Palacio Nacional y que esa noche se suspenderían las hostilidades. Entre otros españoles, Cólogan informó de dicha situación a algunos miembros del Casino Español para que "puedan los españoles y sus familias dormir tranquilos esta noche". Al día siguiente, apareció en El Universal una nota diciendo:

Ya para entrar en prensa nos llegó la noticia, por conducto del Casino Espańol, que fue comunicada por el señor ministro de España, que el señor presidente Madero renunció, así como su gabinete.

Por supuesto Cólogan se contrarió e inmediatamente después de leer la noticia se encaminó al Casino. Llegó tan sólo a las puertas donde encontró a una gran cantidad de españoles, no todos socios, aunque sí reconoció a unos cuantos.

No me detendré en los datos específicos, sino más bien en lo que éstos significaron. Cólogan reclamó el hecho de divulgar semejante nota y dijo:

¿Cómo es que estas espontaneidades mías en favor de ustedes puedan resultar contraproducentes? ¿Qué se ha hecho para cumplir la imperiosa necesidad de destruir el grandísimo peligro en que esa publicación pone la vida de los españoles, que no cuentan con las paredes fortificadas del Casino o de sus grandes casas de habitación?, ¿con qué derecho tergiversan mis palabras?, ¿quién fue ese imbécil?

Todo esto, por palabras del propio ministro, fue dicho con gran vehemencia a las puertas del Casino, al cual nunca ingresó. 
Lo que preocupaba al representante español, más que su propio ridículo ante toda la ciudad y el gobierno mexicano, era el hecho de que por comentarios hechos en el Casino, que

según fue sabido de todos, llegó a ser foco de antimaderismo, y aunque con sus 700 socios está hoy muy lejos de representar a una colonia de 12000 españoles en el Distrito Federal,

para el público mexicano éste apareciera como un ejemplo generalizado de toda la colonia. Es decir, su interés era que ni el gobierno mexicano, ni la sociedad en su conjunto pensaran que si el Casino era tan evidentemente huertista, toda la colonia lo era también. Su posición, como ya dije anteriormente, fue la de abogar por la legalidad en México, sin importar realmente quién estaba en la silla presidencial. Por otro lado, Cólogan no quería que sus acciones, que eran bien intencionadas, se tomaran a mal. Él creía que las preferencias políticas de estos españoles no les traerían nada bueno, pero lo que más le preocupaba era el bienestar de toda la colonia española, y fue por lo que más trabajó. "No hagas cosas buenas que parezcan malas", debe haber pensado Cólogan. Lo que hizo fue simplemente aconsejar a los espańoles que no se metieran en la política y en los conflictos mexicanos porque las consecuencias podrían no ser buenas e incluso contrarias a sus intereses. ${ }^{78}$

${ }^{78}$ Toda la información anterior proviene de un informe del ministro Cólogan al ministro de estado de España. Archivo Histórico de la
El siguiente paso lo dio el Casino, el día 25 de febrero, cuando por casi unanimidad de votos en sesión de la Junta Directiva se envió una carta al ministro español pidiendo explicaciones por el incidente ocurrido a las puertas del Casino. ${ }^{79}$ La respuesta de Cólogan, inserta en el libro de actas del mismo día, tiene cierto tono de indignación, pues más que dar explicaciones sostiene que sus actos iban encaminados a cuidar y velar por el bienestar de toda la colonia española, y que los que debían una explicación eran los propios miembros del Casino o quien quiera que hubiera utilizado su nombre para dar tal información a El Universal.

Por otra parte, al final del informe enviado al ministro de Estado en Madrid, Cólogan criticó duramente a los miembros del Casino y sobre todo a los de la Junta Directiva, en especial al presidente Eusebio González. Habló de ellos como "señorones, engreídos por sus millones o grandes negocios", y terminó diciendo que para tener "prestigio y representación reconocida no basta resguardar alhajas, caudales y personas". Él estaba tranquilo por su actuación en México y su desempeño oficial al cuidar a los españoles:

sé también la altura en que dejaré la representación de España a juzgar por la inmensa mayoría de los españoles (salvo los consabidos energúmenos de

Embajada de España en México (en adelante AHEEM), microfilm en El Colegio de México, rollo 47 , caja 292 , leg. 2 , núm. 3,16 de marzo de 1913,6 pp.

79 BACEM, Libros de Actas núm. 7, 27 de febrero de 1913, fs. 23-23v. 
la Junta Directiva del Casino y los a ellos apegados) y lo que me demuestra la sociedad mexicana "en masa". ${ }^{80}$

No obstante estas rencillas, a mediados del mismo año de 1913 "los directores del Casino solicitaron una entrevista con objeto de cumplimentar oficialmente al representante de nuestra patria." 81 Fue así que varios miembros de la Junta Directiva visitaron a Cólogan y éste correspondió la visita en el Casino, donde "fue afable y amistosamente acogido". Seguramente esto se debió a que el presidente del centro ya no era Eusebio González, de quien tan mal había hablado Cólogan, y que el nuevo, Valentín Elcoro, no era tan contrario a las políticas del ministro respecto a la colonia.

Pero las diferencias no terminaron ahí. Cuando la retirada del ministro era ya un hecho, el Casino decidió ofrecer un banquete en su honor. De nuevo por un malentendido a través de un diario, la fiesta no se pudo llevar a cabo. Al parecer, Cólogan se enteró del festejo por la prensa y a través de ese medio les contestó, lo cual molestó a la Junta que esperaba que lo hiciera personalmente. ${ }^{82}$ Lo que queda claro es que realmente no había intención de las partes por solucionar el desaguisado ni que el banquete se llevara a cabo. A pesar de todo, el Casino no podía quedarse de brazos cru-

Bo AHEEM, rollo 47, caja 292. leg. 2, núm. 3, 16 de marzo de 1913.

: "Casino Español", El Correo Español, año XXV, núm. 6891, 10 de julio de 1913.

${ }^{82}$ BACEM, Libros de Actas núm. 7,30 de noviembre de 1912, f. 19v. zados y no hacer nada respecto a la partida del ministro y decidieron hacer una placa de oro conmemorativa con las armas nacionales y con una expresiva dedicatoria. $^{83}$

Al irse Bernardo de Cólogan llegó a México un agente confidencial encargado de informar acerca de la situación política en México y de los españoles residentes. Sus informes los tenía que presentar al embajador de España en Washington, Juan Griaño y Gallangos. La principal intención del agente confidencial Manuel Walls y Merino fue acercarse a los residentes e intentar hacerles entender que no debía existir participación política de su parte. Por los informes que rindió a sus superiores, el agente Walls llegó a México con amplia noción del asunto. Sabía que los españoles, sobre todo, cierto sector de la colonia, no se había mantenido del todo alejado; sabía también del abierto antimaderismo de los miembros del Casino y de su apoyo a Huerta y Félix Díaz. Pero la situación política había cambiado en México desde la nefasta publicación del artículo en $E l$ Universal durante la Decena Trágica, hecho que tanto Walls y Merino como Cólogan consideraron siempre como lamentable y peligroso para los españoles.

La actitud de muchos españoles, ejemplificada en la elite casinista, hizo que Carranza se mostrara contrario a los miembros de esta colonia extranjera y los persiguiera. Walls previó el

${ }^{83}$ Ibid., 13 de julio de 1914, f. 71; "Viaje del ministro de España", El Correo Español, año Xxvi, núm. 7203,8 de agosto de 1914. 
peligro y su principal tarea al llegar a México fue prevenir a sus compatriotas. Una de sus primeras acciones fue ir a ver a Adolfo Prieto y al presidente del Casino para tratar de hacerles ver su riesgosa posición y aconsejarles que actuaran con cautela. Para este momento ya se sabía que Carranza entraría triunfante a la ciudad de México.

La noche del 26 de agosto de 1914, pocos días después de la llegada de los constitucionalistas, un grupo armado ingresó al Casino Español. Los socios, seguramente en medio de partidas de dominó y de paco, fueron echados de su propio local. Walls y Merino se enteró del asunto a la mañana siguiente y se reunió con Isidro Fabela, a la sazón secretario de Relaciones Exteriores. Éste lo condujo a su oficina donde aclaró el problema asegurando que ya había pasado el peligro y que el Casino se cerró porque se le creía un reducto huertista. Las autoridades militares de la ciudad dijeron tener noticias de un movimiento contrarrevolucionario y pensaron que elementos huertistas podrían esconderse en el edificio de Isabel la Católica.

El presidente del Casino fue informado que el lugar podía abrir de inmediato, pero no sin antes recomendarle prudencia, sobre todo por las noches, sobre a quién se le abrían las puertas. Walls y Merino, a su vez, hizo otra recomendación al presidente Zavala pidiéndole que mantuviera las puertas cerradas ya que seguramente todos los socios estarían indignados y se sabía qué podrían hacer. El agente conocía muy bien esas reacciones de aquellos españoles y las actitudes sobre su propia seguridad. El presidente de la Junta escuchó el consejo y decidió que no notificaría a la Junta Directiva que estaba autorizado para la reapertura y que lo haría hasta que las cosas estuvieran calmadas. ${ }^{84}$

Como tantas otras cosas trascendentales, ésta tampoco fue mencionada en las actas; simplemente se advierte que no hubo sesiones entre el citado día de agosto y mediados de diciembre de 1914. El día 16 aparece un informe acerca de toda la situación:

El señor presidente, en virtud de la amplia facultad que se le concedió con motivo de los sucesos acaecidos en la noche del 26 de agosto próximo pasado por un grupo de fuerza armada perteneciente a los carrancistas, y cateo llevado a efecto el día 17 de septiembre anterior, dio cuenta de sus gestiones en pro de la apertura del Casino, la que no creyó conveniente tuviera efecto hasta la fecha de todos conocida por las razones de prudencia e interés en obsequio de la sociedad que aconsejaban las circunstancias extraordinarias porque atravesaba la capital. ${ }^{85}$.

El Casino se volvió a abrir el 15 de diciembre y la noticia fue dada a la colonia española, y a la sociedad mexicana en su conjunto, a través de $E l$ Correo Español:

Pueden, pues, desde ahora, concurrir a la casa hispana todos los socios que lo deseen libremente en la seguridad de no ser molestados, pues las autoridades

${ }^{84}$ MacGregor, "Agentes", 1992. Parte de esta información me fue proporcionada por la propia doctora MacGregor.

${ }^{85}$ BACEM, Libros de Actas núm. 7, 16 de diciembre de 1914, fs. $72 \mathrm{v} .-73$. 
han concedido el permiso para la reapertura. Lo celebramos. ${ }^{86}$

Terminaba así, la etapa de auge y esplendor del Casino Español de México. Carranza, por obvias razones políticas, nunca fue invitado al Casino. A partir de este momento, el papel del Casino se vio reducido a tener una presencia dentro de la colonia española que, aunque nunca fue tan fuerte como en la época antes reseñada, sí continuó representando a un sector importante de la colonia, así como siendo un importante punto de contacto con la sociedad mexicana.

\section{CONCLUSIONES}

Las condiciones políticas y sociales de finales del porfiriato favorecieron el surgimiento del grupo que conformó el Casino Español de México. En una época en que la importancia de las elites extranjeras era notoria, ésta fue aprovechada por ellas mismas logrando ocupar un alto puesto que las favoreció tanto económica como socialmente. Los españoles de la calle de Isabel la Católica, en su mayoría hombres de negocios y exitosos empresarios, se convirtieron en personajes respetables, en quienes se veía un modelo a seguir, sobre todo dentro de la colonia española. Prácticamente todos ellos llegaron con muy poco o nada de fortuna y conformaron su alta

86 "El Casino Español", El Correo Español, año xxvı, núm. 7313 , jueves 17 de diciembre de 1914. posición en México. Esto poco a poco los fue colocando en un lugar predominante dentro de la sociedad mexicana, a la vez que explica su cercanía con el dictador y con su gobierno.

Este grupo, al conformarse como una elite social y económica se convirtió también en excluyente y el Casino Español se estableció como una sociedad exclusiva. Como se vio, en un principio no tuvieron especial interés por relacionarse con la sociedad mexicana desde otro punto de vista social que no fuera el necesario para mantener sus relaciones económicas y comerciales; buscaron, entonces, mantenerse ligados a España y de los acontecimientos ibéricos. Al pasar de los años la importancia de sus negocios y empresas contribuyó a que se abrieran a la sociedad mexicana, pero procuraron hacerlo solamente en el grupo equivalente al de ellos, es decir, a la burguesía capitalina, a empresarios y hombres de negocios y a la esfera política nacional. Esto obedeció, a mi parecer, a dos cuestiones fundamentales. En primer lugar, el hecho de que el Casino creciera en número fue resultado de la consolidación de la misma elite de la colonia española, es decir, en el momento en que sus miembros decidieron socializar con los mexicanos ya estaban conformados como una sociedad próspera y estable, cuyos miembros más destacados eran prominentes hombres de negocios reconocidos en todo el país. Por otro lado, estas posiciones económicas les obligaron a entablar relaciones de tipo social y político con empresarios mexicanos, así como con miembros del gobierno porfirista, gracias a quienes, según los 
españoles, habían podido trabajar y crear sus fortunas.

Fue así que los espacios de socialización de los españoles del Casino eran distintos de aquellos del resto de su colonia. Supieron aprovechar la política del porfiriato, e ingresar al círculo de la burguesía mexicana y de la elite de los demás centros extranjeros. Se identificaron más con aquellos que concurrían a las carreras de caballos y a los bailes y fiestas de los diplomáticos que con sus compatriotas menos existosos. Por lo mismo, no se puede decir que el Casino Español haya sido, y mucho menos sea, el representante "oficial" de la colonia española en México.

Los propósitos del Casino Español como asociación cambiaron durante el periodo que se analizó en las páginas anteriores, pero en el fondo mantuvieron una misma línea. Estos españoles tuvieron la intención de unirse gracias a los lazos comunes: su nacionalidad y el papel que comenzaban a jugar en México como hombres de negocios. Nunca estuvo dentro de sus propósitos convertirse en una sociedad de ayuda para la colonia española, ya que sus funciones no estaban encaminadas a satisfacer las necesidades de los trabajadores inmigrantes; para eso estaba la Beneficencia Española. Ellos pretendieron más bien unificar a los miembros de la colonia española y realizaron actividades encaminadas hacia ese fin, como festejos públicos por efemérides españolas, ciertas actividades para mejorar el nivel de vida de los inmigrantes como fueron las clases sabatinas, etcétera.

Sin embargo, esta unión tan deseada se vio opacada por dos causas fun- damentales. En primer lugar, a partir de la primera década del siglo XX se comenzaron a fundar nuevos centros regionales que estaban en contra de la idea de unir a toda la colonia española. El Casino luchó permanentemente contra éstos en cuanto a que se querían conformar como entidades completamente independientes, ya que sus ideas giraban básicamente en torno a intereses regionalistas. En segundo lugar, y esto es parte de la tesis fundamental de este ensayo, los miembros del Casino Español de México, especialmente aquellos que lo dirigieron, se conformaron como una elite económica y política y comenzaron a utilizar el Casino para mantener y alentar sus relaciones con la jerarquía política y económica del país. La elite española casinista estuvo conformada, como se vio, por empresarios y hombres de negocios que para la primera década del siglo XX eran los dirigentes y dueños de algunas de las principales fábricas y comercios de todo el país, destacándose en la industria textil, algodonera y en los centros financieros. Cuando la revolución cambió drásticamente el curso de la política mexicana, cambió también la posición de los industriales y comerciantes españoles.

El auge del Casino Español, que se dio durante la primera década del siglo XX cuyo apogeo fueron las fiestas del centenario donde los socios pudieron hacer público su agradecimiento a Porfirio Díaz así como su cercanía con el gobierno; se vio truncado, entonces, con la salida del general. Los temores de los representantes diplomáticos Cólogan y Walls y Merino resultaron estar bien fundados, y la con- 
traria actitud de estos españoles hacia Madero y la abierta simpatía por Huerta hizo que la suerte se volteara contra ellos. Con la llegada de los constitucionalistas al poder los miembros del Casino perdieron toda su influencia dentro de la esfera gubernamental, y muchos de sus negocios se vieron grandemente afectados; algunos de ellos incluso tuvieron que salir del país. Los que quedaron lo hicieron a sabiendas de que su situación sería distinta y que tendrían que aprender a adaptarse a un nuevo régimen político que estaba en pro de ideas nacionalistas y que no veía del todo bien a los empresarios extranjeros residentes en México.

\section{ARCHIVOS}

BACEM Biblioteca del Archivo del Casino Español de México, Libros de Actas, 1875-1915.

AHEEM Archivo Histórico de la Embajada de España en México. Microfilm en El Colègio de México.

\section{HEMEROGRAFIA}

El Mundo Ilustrado.

El Correo Español.

\section{BIBLIOGRAFÍ}

- Anuario de la H. Colonia Española de México, s.e., México, 1948.

-Beezeley, William H, Judas at the Jockey Club and other episodes of Porfirian Mexico, University of Nebraska Press, Lincoln and London, 1987.

-Bojórquez, Juan de Dios, La inmigración española en México. Conferencia sustentada ante el grupo cultural "Jovellanos", del Centro Asturiano de México, el domingo 25 de septiembre de 1932, ed. especial de CRISOL, México, 1932.

-Carr, Raymond, España 1808-1939, Ediciones Ariel, Barcelona, 1966. 3 tomos.

-Carreño, Alberto María, Los españoles en el México independiente. (Un siglo de beneficencia), Imprenta Manuel León Sánchez, México, 1942.

-Cerutti, Mario, Empresarios españoles $y$ sociedad capitalista en México 18401920, Fundación Archivo de Indianos, Gijón, España, 1995 (Colección Cruzar el Charco, 15).

-Folleto sobre la ampliación arquitectónica del Casino Español de México, AC. s.p.i.

-Gamboa, Leticia, Los empresarios de ayer. El grupo dominante en la industria textil de Puebla 1906-1929, Universidad Autónoma de Puebla, México, 1985.

-Genin, Auguste, Les français au Mexique du XVI siècle à nos jours, Nouvelles Editions Argo, París, 1931.

-González Loscertales, Vicente, "La colonia espańola de México durante la revolución maderista, 1911-1913", Separata de la Revista de la Universidad Complutense, vol. XXvi, núm. 107, ene.-mar., 1977.

-González Navarro, Moisés, Los extranjeros en México y los mexicanos en el extranjero 1821-1970, El Colegio de México, México, 1994, vol. II.

-Illades, Carlos, México y España durante la Revolución Mexicana, Secretaría de Relaciones Exteriores, México, 1985.

-Kenny, Michael et. al., Inmigrantes y refugiados españoles en México siglo XX. Ediciones de la Casa Chata, México, 1979.

-Lida, Clara E. (coord.), Tres aspectos de la presencia española en México durante el porfiriato, El Colegio de México, México, 1981.

(comp.), Una inmigración privilegiada. Comerciantes, empresarios 
$\begin{array}{lllllllll}E & X & L & I & B & R & I & S\end{array}$

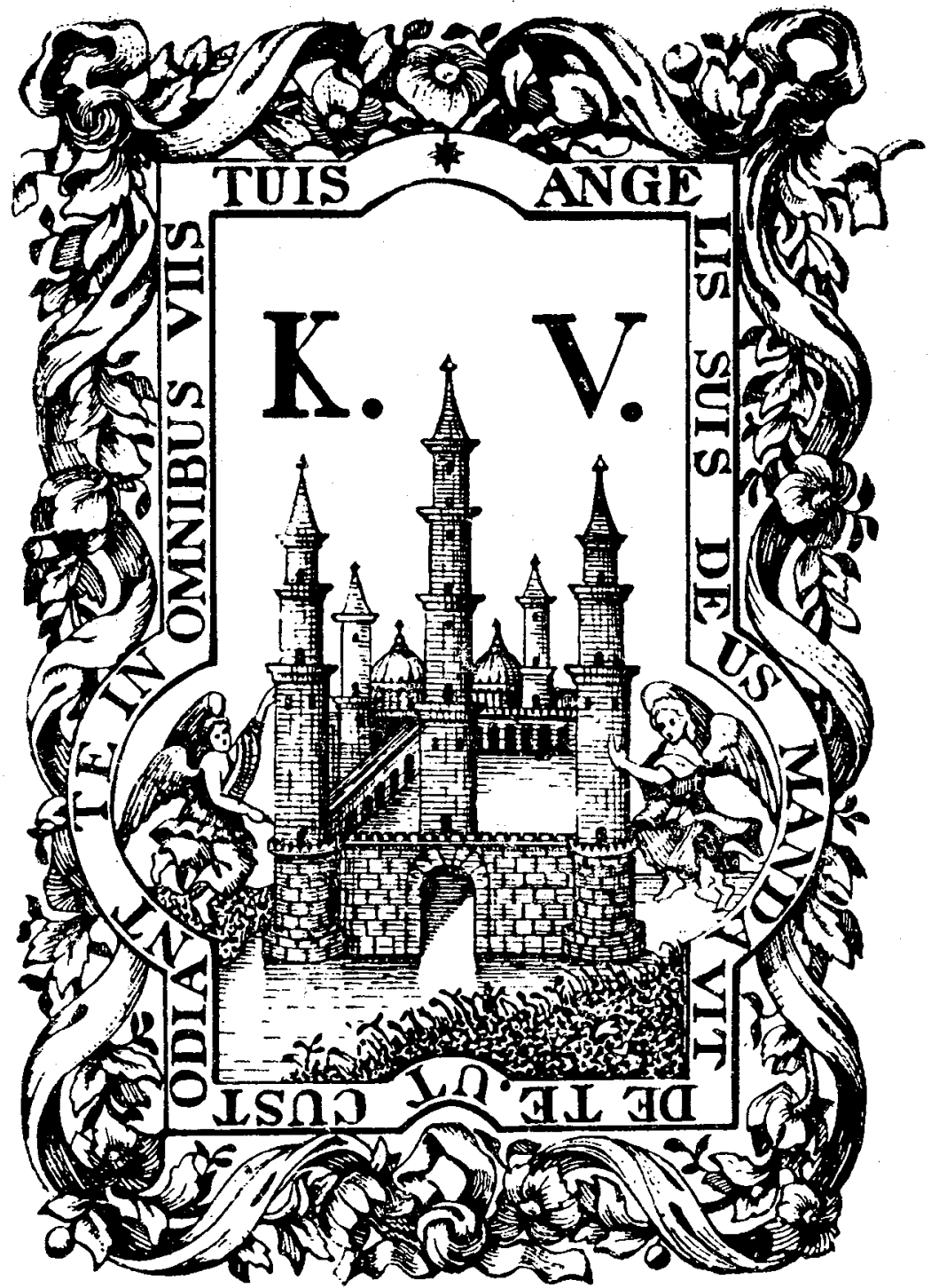

ERNESTO DE LA TORRE VILLAR 